\title{
Tørst og tekst
}

\author{
Bemærkninger om læserens tunge, som den er indskrevet \\ i Rabelais' bøger om Gargantua og Pantagruel
}

\author{
JAN BÄCKLUND
}

\author{
Non est dithyrambus si bibit aquam \\ (Erasmus, Adagia IV.III.58) \\ J'ay la parolle de dieu en bouche: Sitio \\ (Garg., V)
}

Første gang jeg havde lagt mig tilrette i min sofa og proppet en flaske vin op for at give mig i kast med Rabelais' fem bøger om Gargantua og Pantagruel i C.E. Falbe-Hansens oversættelse (ja, jeg må have haft det på fornemmelsen), indtraf noget, som jeg hverken tidligere eller siden hen har oplevet. Jeg var ikke kommet langt ind i forordet af den første bog, Gargantua, førend mit humør var i top, og da forfatteren afsluttede sit forord med følgende opfordring:

Glæd jer da, mine elskede Venner, og læs Resten med muntert Sind til Lyst for jeres Krop og til Gavn for jeres Nyrer! Men I dumme Æselfjæs — gid Chancren maa gøre jer halte! — hør vel efter og husk at drikke min Skaal; jeg skal paa Stedet gøre jer Besked. (Garg., Prol.) I

... løftede jeg selv glasset og skålede med bogen jeg holdt i højre hånd. Jeg har siden hin aften for tolv år siden ikke kunnet glemme denne episode, og dette til trods for at den vejer så lidt, er så ubetydelig og i den grad vilkårlig, dvs. afhængig af så mange andre ukendte parametre end lige de rent litterære - hukommelsens vægt og fylde har den alligevel bevaret. “At skåle med en bog” bar en form for kondensering af betydning med sig - om end af den mere stille slags -, et sammenfald eller kollaps indeholdende en vis grad af opbyggelighed, eller måske rig- tigere: af litterær krise - ja, lad os sige "en rasen", da jeg stadig er usikker på, hvorvidt det var selve handlingen at skåle med bogen, eller forordets rystende kraft, som forårsagede en vis svimmelhed, og som tvang mig til at lægge bogen og stille glasset fra mig for at gå gestikulerende frem og tilbage i mit lille værelse som, forestiller jeg mig, en bokse-champ i et omklædningsrum. Selv har jeg ikke desto mindre svært ved at ryste fornemmelsen af, at selve handlingens løjerlighed, altså udbringelsen af skålen, dækker over et mere centralt forhold mellem tekst og læser, et forhold som mødes i beruselsens 'raseri', i en form for fureur poëtique som det heder i Cinquiesme Livre. Jeg tror nu ikke, vi taler om et sammenfald af fiktion og virkelighed, af udsagn og handling eller af potentialitet og aktualitet. Ikke desto mindre var det sandsynligvis en lignende type af sammenfald som kom til at fungere bestemmende for den noget negative og moralsk indignerede reception af Rabelais, som vi kender fra det $17.0 g$ I8. århundrede, hvilket dog i det mindste antyder, at vi ikke har været de eneste, som er kommet til at skåle med de forskelligt indbundne udgaver af værkerne gennem tiderne. På den måde kunne en stor mængde læsere anskue Rabelais som en drukkenbolt (un bienyvre), eftersom teksten var en samling skåler, sludder og løs snak (propositions). En sådan umiddelbar årsagssammenkædning af læser, tekst og forfatter ville så betyde, at tekstens muligheder aktualiseredes i skålen (eller det ambulant gestikulerende), eller at tekstens formål er at fremprovokere det samme. Men vi vil alligevel her fastholde den momentane kollaps og dens, om end diskrete, betydningsfylde.Vi 
møder også denne type af kollapser i en række andre typer af tekster; hvem er ikke i en art litterært raseri mod, eller mere almindeligt med teksten, blevet nødt til at lægge bogen fra sig og fortsætte (typisk netop ambulant gestikulerende) sin læsende tekst, netop som et slags 'svar' på det læste, som en form for returneret skål?

\section{Skål og tiltale}

Ser man kort efter, så finder man hurtigt, at det alene er $\mathrm{i}$ forordene, at forfatteren (i de to forste bøger kvintessensudtrækkeren Alcofribas, i de tre sidste medicindoktoren Rabelais) adresserer sig direkte til læseren, der typisk adresseres i forordenes allerførste linje: Beuveurs tresillustres, et vous Verolez tresprecieux ... (Garg.); Tresillustres et Treschevaleureux champions, gentilz hommes, et aultres ... (Pant.); Bonnes gens, Beuveurs tresillustres, et vous Goutteux tresprecieux, ... (Tiers); Beuveurs tresillustres, et vous goutteurs tres precieux, ... (Quart I548); Beuveurs infatigables, et vous verollez tresprecieux ... (Cinq.). Disse overordentligt muntre tiltaleformer stemmer umiddelbart den velvillige læser til en, hvis ikke uvant, så i hvert fald tydeligt understreget modtagerposition. Denne 'positionsbestemmelse' af læseren bliver endnu mere fremhævet i det forord, vi sprang over, nemlig det nye til Quart Livre, netop til "De velvillige Læsere" (Au lecteurs benevoles) fra I552, hvor der lægges lidt anderledes ud med:

Pæne Folk! Gud frelse jer og bevare jer! Hvor er I henne? Jeg kan ikke se jer.Vent lidt, at jeg kan tage mine Briller paa! Ha, ha! Filippine! Nu kan jeg se jer. I har haft en godVinhøst, efter hvad man fortæller. Det var saa sandelig ikke ilde nyt. I har dèr fundet et ufejlbarligt Middel mod Tørst. ${ }^{2}$

Om end i en mere skjult form finder vi samme tiltaleform i forordet til Gargantua, hvor vi kan konstatere, at forfatteren er en, der engang imellem drikker som os, og at vi, paradventure, drikker som han. ${ }^{3}$ Når samme forfatter fortsætter med at bekende, at han ikke har ofret anden tid med denne bog end med at spise og drikke, såsom "det udødelige mønster" Homer forstod at gøre det, og såsom Ennius, de latinske digters fader, forstod at gøre det, og dette til trods for at en ussel mand havde sagt, at hans vers lugtede mere af vin end olie:

Det samme har en elendig Kludderhas [tirelupin] sagt om mine Bøger; men skidt med ham! Lugten afVin! Den er da saa langt mere lækker, lattervækkende og tiltrækkende [friant, riant, priant], mere himmelsk og liflig end Lugten af Olie. Og jeg vil regne mig det i ligesaa høj Grad til Ære, at man siger om mig, at jeg har givet mere ud til Vin end til Olie, som Demosthenes gjorde det, naar man sagde om ham, at hans Udgifter til Olie var større end til Vin. For mig er det kun en Hæder og Ære at nævnes og berømmes som en god Kammerat og Selskabsbroder; [...]. (Garg., Prol.)

Svarende til den direkte tiltale til læseren er det også kun i forordene, at der i den grad monumentalt opfordres til at drikke. Ikke fordi der bliver spyttet $\mathrm{i}$ glassene af Pantagruel, Panurge, Epistemon eller Broder Johan, men deres drikkeri er trods alt tredje personens drikkeri, medens forordene omhandler den anden persons drikkeri, altså "du" og "I". Når vi kommer til selve bøgerne, så har fortælleren trukket sig tilbage til sin refererende stemme. Bortset dog fra de tre sidste kapitler i Pantagruel, hvor jegfortælleren hastigt og ganske umotiveret dukker op i handlingens tid og rum. I det toogtredivte kapitel befinder han (Alcofribas Nasier) sig på Pantagruels tunge (langue), i det efterfølgende er han - i egenskab af læge - nede i Pantagruels mave, og i det afsluttende, "Afslutningen af nærværende bog, og forfatterens undskyldning”, beskriver jeg-fortælleren, hvad den kommende bog vil indeholde, og at den vil kunne købes ved næste bogmesse i Frankfurt. Det er vores idé her, at det er dér, nede i Pantagruels bug, mellem det talte ord (tungen) og den bog (flasken), som læseren har i hånden, vi kan finde en forklaring på vores latterlige skål.

Her placerer prologerne sig som en art dublering, en ydre omkransning, af de konversationer, som forekommer i selve krønikerne. Sådan her f.eks.: når Pantagruel for første gang møder Panurge, så vægrer denne sig ved at fortælle sin historie, hvis han ikke får noget at spise og drikke, og da han omsider kommer i gang, i det fjortende kapitel, er det først efter, at han har fảet noget til tanden. Temaet er selvfølge- 
lig gennemgående $\mathrm{i}$ alle fem bøger: inden hver fortælling og, måske overflødigt at tilføje, efter hver episode skal der drikkes en skål: "Un peu et $d u$ bon" ville ikke være forkert, men "beaucoup et $d u$ bon" ville være det helt rigtige. Måske er dette præliminære, eller 'prologiske' druk tydeligst artikuleret, når den engelske filosof Thaumaste kommer for at disputere med Pantagruel om alle verdens hemmeligheder kun ved hjælp af tegn (Pant., XVIII). Pantagruel (som også, til de skandinaviske oversætteres glæde, udvikler sig til noget af et dydsmønster efter at han møder Panurge) sætter sig umiddelbart ned for at studere:

Le livre de Beda de numeris et signis.

Le livre de Plotin de inenarrabilibus.

Le livre de Procle de magia.

Les livres de Artemidore peri onirocriticon.

De Anaxagoras peri semion.

D’Ynarius peri aphaton.

Les livres de Philistion.

Hipponax peri anecphoneton, ...

Suppleret af en bunke af anden, relevant litteratur, ville vi vel alle sige. Men ikke Panurge. Han foreslår at overtage Pantagruels rolle, for at selv at disputere med Thaumaste, og sætter sig til at forberede sig på en ganske anden måde, nemlig ved at skifte bogen ud med flasken og tilbringe natten med at chopiner avecques les paiges, altså ved at svinge bæger med tjenerne. Her svarer Panurges vandel (drikkende og fortællende) i forhold til Pantagruel (læsende og lyttende) til forfatteren af forordets fremtræden (drikkende og skrivende) i forhold til læseren (læsende og lyttende), samtidigt med at forordet udgør en koncentrisk omkransende rammefortælling af alle krønikernes fortællinger.

Ligesom krønikerne er indrammede af drikkepauser af tilpas frekvens, fungerer prologerne som læserens nødvendige forberedelser til teksten. Prologen er noget, som indleder teksten, eller rettere: ordet og læsningen, noget, som er før ordet, ligesom skålen er noget, som indleder drikkeriet. Det er ikke drikkeriet selv, som er sagen, men det er frem for alt en indledning, en indbydelse til at fortælle, og skålen er altså samtidig en indbydelse til konversation. Skålen er i sin form dialogisk, den er et møde mellem to bienyvres. Vi ser denne - om end af forfatteren postulerede - dialogiske placering af sin egen udsagnsposition og en kuriøs indskrivning af læseren i slutningen af det meget omdiskuterede forord til Gargantua: "Derfor skal I fortolke alt, hvad jeg gør og siger, paa allerbedste Maade; og nære dyb ÆErbødighed for min osteformede Hjerne, der fodrer jer med dette fagre Hjernespind, og sørg for altid at holde mig lystig saa godt I formaar.” 4 Læseren skal altså holde forfatteren lystig, så godt han formår, hvilket jo også bliver understreget med det citat, som vi skålede med, og som følger umiddelbart efter: boyre à $m \gamma$, dvs. drik min skål, eller, hvis man er til ordspil: drik, min ven!

Sandsynligvis er det også derfor, forordene har den form de har: Forfatteren anstrenger sig for at se os, han har hørt om os (om vores vinhøst), og han tiltaler os (drikkebrødre og syfilitikere) og giver samtidig sig selv til kende. Som hvad, spørger I? Som Alcofribas Nasier? Som udtrækker af kvintessensen? Ja, sikkert, men det bliver vi jo ikke meget klogere af. Snarere kan man paradoksalt sige det sådan, at forfatteren giver sig tilkende som den tekst vi læser ("at holde mig lystig saa godt I formaar”). Det vil være konklusionen af vor latterlige handlings forsvarstale, at læseren underholder forfatteren/bogen/flasken med dens mening/tekst/indhold. Deraf beruselsen, une aureille, bien drappé (Garg., v) 5 og vor argumentation vil være et forsøg på at udrede, hvordan en sådan omvending vil kunne lade sig gøre (vel vidende at det ikke vil lykkes os).

Bog og flaske

Om end Rabelais aldrig slipper sit fokus på det talte ord, nemlig det, at teksten skal læses og ordene ligge på tungen, så spiller ikke desto mindre selve bogen, den trykte bog, en afgørende rolle for læserens møde med teksten. På den ene side som en slags sikkerhed, som i forordet til Pantagruel, hvor læseren opfordres til at lade "sin daglige Dont ligge" og slet ikke bekymre sig om sit fag og sine forretninger for at lære de nævnte krøniker udenad "dersom Bogtrykkerkunsten tilfældigt hørte op at eksistere, eller i Tilfælde af, at alle Bøger gik til Grunde, kunde hver 
enkelt i kommende Tid i klare Ord fortælle dem og række dem som fra Haand til Haand til sine Efterkommere og Efterlevende som en from Kabala" (Pant., Prol.). På den anden side har flasken også det tilfælles med bogen, hvad Marshall McLuhan er opmærksom på i The Gutenberg Galaxy, at trykpressen bygger på en teknologi, som den lånte fra vinpressen; i bogtrykkeriet presses bogstaverne frem af de løse typer mod papir, som var den kvintessensen presset fra druer. Det giver sig selv, at hvis flasken er fyldt op med vin, så er bogen fyldt op med tekst, og den metaforiske lignelse mellem flaske og bog er også et mere eller mindre gennemgående tema i Rabelais' bøger. De optræder i form af tvetydigheder omkring vade mecum (såvel lommelærke som almindelig brugt bogtitel), men samme tvetydigheder sættes også i spil med hensyn til breviaire: Un beau et ample breviaire, en god og velskænket bønnebog, som det hedder i I548-Prologen til Quart Livre6 eller horaire, tidebog, som vi så i kapitlet "Les Propos des bienyvres", og når der skal drikkes, skal der gerne drikkes en bon traict eller à grands traictz, en for tiden overtydelig sammenkædning af slurke og afhandlinger.

Tydeligst og mest ekspliciteret er selvfølgelig denne metafor $\mathrm{i}$ den femte bogs illustration af en bouteille indeholdende tekst, ganske som om trykpressen har frempresset denne dityrambe fra løse blytyper, som var det vin fra druer, og fyldt dem på en flaske:

Flaske huld,

Løndomsfuld!

Med ét Øre

Vil jeg høre.

Tøv ej længer,

Udtal nu det Ord,

hvortil haardt mit Hjerte trænger.

I din Guddomsvædske bor,

Guden holder dér den lejret,

Bacchus, han, der Inderne besejred',

Sandhed, Sandhed kun derinde gror.

Vin, du Guddomsdrik, bestandig er du fri,

Fri for Logn og lumsk Bedrageri.

Noahs Sjæl skal Saligheden have,

At han gav til os din Guddomsgave.

Hør, jeg beder, du dit Ord vil raabe,

Der kan fri mig af min dybe Nød.

Ej jeg spilde skal en Draabe,

Er den hvid, hvad heller rød.

Flaske huld.

Løndomsfuld!

med ét Øre

Vil jeg høre.

Tøv ej længer!

At denne funktionelle identitet mellem bogen og 
flasken i allerhøjeste grad gælder Rabelais' egne bøger fremtræder også i den Fjerde Bogs prolog fra I548, hvor forfatteren glæder sig over, at "den Tredje Bogs vin", altså teksten tappet i den Tredje Bog, har været god og i vores smag.7

Men hvis altså teksten er tappet på en flaske, så er det læserens arbejde at proppe den op, ganske som man åbner en bog. Et tema som også er tydeligt fremhævet i forordet til Gargantua, hvor læserens arbejde med at åbne bogen lignes ved hundens - det mest filosofiske af alle dyr - arbejde med at finde $l a$ sustantificque mouelle $\mathrm{i}$ et ben:

Har I nogensinde aabnet et Skab for at stjæle en Flaske? Ja, Død og Pine! [den Tave!] Husk saa, hvorledes I bar jer ad. Og har I nogensinde set en Hund finde et Marvben? [...] Dersom I har set det, har I sikkert lagt Mærke til den Andagt, hvormed den beskuer sit Bytte, den Omhu, hvormed den vogter det, den Lidenskab, hvormed den holder det fast, den Klogskab, hvormed den gaar i Gang med det, den dybe Lyst, hvormed den knuser det, og den Nidkærhed, hvormed den slikker Marven i sig. [...] Efter denne Hunds Eksempel maa I ogsaa være kloge nok til at lugte, vejre og værdsætte disse skønne saftrige Bøger, der tilsyneladende er saa lette at jage, og dog saa vanskelige at tage det op med. ${ }^{8}$

Sokrates lignes i det samme forord ved Bacchi latterlige og frivole silener; han var "tarvelig i Sæder, bondeagtig i Klæder, fattig paa Formue og ulykkelig i sit Ægteskab, uegnet til alt Arbejde i Statens Tjeneste, bestandig grinende, bestandig drikkende omkap med enhver, bestandig spottende, for bedre at skjule sin guddommelige Viden.” Men når man åbner denne æske (boyte), altså Sokrates latterlige ydre, eller denne flaske eller bog, finder man derinde et himmelsk og uvurderligt lægemiddel. Den påhæftede etikette, dvs. bogens titel, fungerer dissimulatorisk i forhold til det guddommelige indhold, den skjuler. Men Sokrates, ligesom Homer og Kristus, skrev som bekendt ingen bøger, og hældte heller ikke sin vin på flasker. Når hverken Sokrates, Homer eller Kristus skrev, betyder det også, at de ikke kan læses, men så at sige er 'teksten' selv (et forhold som er endnu tydeligere mht. muslimers forhold til Koranen, som ikke er en af Guds skabelser, men et af
Guds attributter), som man kun konversatorisk kan repetere videre, hvad jo Rabelais også havde opfordret til i forordet til Pantagruel. Her er det nok heller ikke helt ved siden af at minde om, at Rabelais grundlæggende cynisk, dvs. køteragtigt, digter videre på en allerede kendt historie. Teksten skal så at sige ligge på tungen, tales; læseren skal finde til tekstens kilde, eller 'marv', la sustantificque mouelle, ved hjælp af en slags gnavende, dvs. repeterende tale.

\section{Torst og tale}

Det var også under hundedagene, nærmere bestemt den 25. juli, hvor alle tørster, at Pantagruel kom til verden, denne dæmon som kaster salt i de sovendes snorkende gab, så de bliver overmandede af tørst (Gargantua er født fra Gargamelles øre, "une aureille, bien drappé”, på Den hl. Blasii dag, den 3. februar, som var strubens og halsens skytshelgen). Det var også som en veritabel saltleverandør (marchand $d u$ sel, som Marcel Duchamp senere titulerede sig), at Pantagruel bliver født, og selve nedkomsten annonceres, ja, indledes, med en imponerende karavane af tørst, et tørstens triumftog, i Pantagruels andet kapitel:

Thi da hans Moder, Badebec, fødte ham, og Jordemødrene ventede paa ham, var det første, der kom ud af hendes Bug 68 Muldyrdrivere, der hver holdt et Muldyr, fuldt belæsset med Salt, ved Grimen; efter dem kom ni Dromedarer, belæssede med Skinker og røgede Oksetunger, syv Kameler med saltede Aal; derefter 25 Vognlæs Purrer, Hvidløg, Løg og Chalotter, hvad der i høj Grad forbavsede de nævnte Jordemødre. Men nogle af dem sagde:

- Det var et godt Beredskabslager. Hidtil har vi bare drukket som en Løjser, ikke som en Svejtser. Det kan kun være et godt Tegn; det er den Slags der ægger Tørsten. ${ }^{9}$

"J'ay la parolle de dieu en bouche: Sitio." Jeg har Guds ord i munden: Jeg tørster, med tydelig henvisning til Vor Frelsers ord på korset (Joh. XIX, 28), er et af Rabelais mange tillæg til det femte kapitel af I542-udgaven af Gargantua, "Les propos des bienyvres", eller "Drukkenboltenes passiar", som det hedder hos Falbe-Hansen. Dette femte kapitel er en mærkelig sammensætning af sætninger, interjektioner, korte meningsudvekslinger og brudstykker af 
sætninger, ikke sjældent med (tæt på blasfemiske) gammeltestamentlige parafraser, evangeliske ord, lignelser fra hellige mænd (Augustin), parodier på skolastiske læresætninger, gendigtninger af salmer, og hvor han ellers har kunnet finde argumenter ad bibendum. Der lægges nu relativt stille ud: "Derefter faldt de i snak på stedet og snakkede løs ved gildet, hvor de sad. Og nu begyndte flaskerne at gå: skinkerne trave, bægerne flyve, krukkerne ringe”, men derefter, inden for et citattegn som varer kapitlet ud:

Træk, ræk, fyld, bland. Hid, til mig, uden vand, så min ven, tøm mig det glas galant i et drag, jeg indkalder rosévinen til vidne, glasset til bredden. Ro på tørsten. Ha, febertørst, skal du ikke snart drage afsted? På hæder svigermor, jeg er ikke kommet i gang med at pægle endnu. Er De forkølet lille ven? Mon dog. Ved Den hl. Qenets Bug, lad os tale drikkeri. Jeg drikker kun til horariet, som pavens æesel. Jeg drikker kun af mit breviarium som en god klosterprior. Hvad kom først: tørst eller druk? Tørst. For hvem vilde have drukket uden tørst da mennesket var uskyldigt? Druk. For priuatio presupponit habitum. Jeg er klerk. Facundi calices quem non fecere disertum ... ... Iо

Og så fortsætter det $\mathrm{i}$ samme stil til slutningen af kapitlet, hvor citattegnet inden rækken af drikkehandlingens fire hjælpeverber ( $j a$, man kunne $\mathrm{i}$ god Laurence Sterne-stil lancere dem som drikkeriets verba auxiliaria, under drikkeriets esse: "bibete"): “Træk, ræk, fyld, bland ...", endelig finder ro efter sidste punktum:

... O svirebrødre, O tørstige sjæle. Tjener, min ven, jeg be’r, kom og fyld min bæger til kanten. Det kardinalsrøde. Natura aborret vacuum.Vil De mene at det er tilpas for hvad en flue kan drikke? På Bretagnernes måde. Tøm glasset i et træk. Ned med det, det er den rene medicin.

Der drikkes bravt og flittigt gennem hele kapitlet, men det er selvfølgelig ikke dette drikkeri, som giver kapitlet dets svimlende og berusende karakter; hvor mange tekster om drikkeri er ikke snarere tragiske og forstemmende, måske sågar kedsommelige, eller; hvor mange tekstlige passager om drikkeri er ikke rent ud ædruelige? Ret beset er det heller ikke det, at der bliver drukket, som er sagen, men at der bliver snakket. Det er ingen dialog, heller ingen monolog; intet ræsonnement, ingen handling: der snakkes løs, "polyfonisk" ville Bakhtin sige. Vi ved ikke, "hvem" som taler, er det en person? Flere? Taler de til hinanden? Taler en person for sig selv, eller taler mange personer for sig selv? Taler nogen med nogen anden? Taler Den hl. Mattæus med en skolastiker? Taler vinen med maden? Taler Augustin til mig? Polyfonisk er tydeligvis det helt rigtige ord. Men desuden: Sætningerne og sætningsfragmenter er stablet horisontalt på hinanden, som en mur af udsagn: en udsagnblok, som er temmelig monumental i dens kompakte sammenvævning af sætninger, sætningsfragmenter og proverbale udtryk. Denne kompakthed forsøger de fleste moderne udgaver at rectificere, som skulle dette polyfoniske vægtæppe sorteres ud i mindre billeder og isolerede episoder. Det gælder bl.a. Falbe-Hansens udgave; han har forsøgt at sortere sætningerne typografisk ud i isolerede stykker og lægger, i klarhedens navn, talestreger og citattegn dertil, hvorfor den monumentalitet, som ordflommen fortjener, tyndes mere end tilladeligt ud. Det siges nemlig ikke, hvornår en tale afløser en anden, og der tales sandsynligvis - sådan oplever, indbilder vi os, de fleste teksten - i munden på hinanden, eller i munden på sig selv. Der tales parallelt, der tales i koncentriske og excentriske cirkler, i digressioner, i ekspliciteringer, der tales diakront (Mattæus ville kunne synes at tale med en unavngiven skolastiker), der tales synkront (ordsprog, salmer, paradokser og bibelord krydser hinanden). Ord falder som parolles gelées (Quart, LV-LVI) ned på tungen (lingua) og smelter som motz de gueule, som ord i munden, men også som "røde ord", altså som rødvin, der flyder ned i struben. Denne proces, at nedfrosne, dvs. skrevne ord smelter (degelent) på tungen og bliver til tale, svarer fuldstændig parallelt til, hvordan vinen flyder ned i struben og bliver til beruselse. Guds ord lagger sig på munden og tørster. Eller måske: Guds ord tages i munden: “jeg tørster”. Det er heller ikke usandsynligt, at nogle sætninger skal tænkes uendeligt repeterede af en eller anden stemme, som om nogen (noget?) stod bagved bestandigt hviskende: beuvez; en anden (noget andet?), hvis ikke fikseret på et 
kors, så måske henslængt på marken, gispende: $j$ 'ai soif. Det er nemlig ingen (renæssancens navnkundige Nemo?) som taler, eller rettere: alle taler, samtidigt, i munden på hinanden, og de bliver ved:

... Jeg nedlægger klage imod tørst, den er lovstridig. Tjener, forbered min klage til retten. Disse vinrester må følge deres leder. Før i tiden plejede jeg at drikke alting op, nu lader jeg ingenting tilbage. Lad os ikke forhaste os, vi skal også få alting med. Se, her er tarme på spil, værd at satse på, og tourainske studemave at byde over med. Drik! eller jeg vil. Nej, nej, drik, jeg be'r. Spurvene vil ikke spise med mindre du klapper dem på halen.Jeg kan heller ikke drikke dersom man ikke taler mig efter tungen. Lagona edatera, det vil sige: Kammerat, lad os drikke! Det er ikke et eneste hulrum i min krop, hvor vinen her ikke snuser sig frem til et tørstigt sted. Denne her pisker tørsten godt op. ${ }^{\text {II }}$

Og så fremledes. Ordsprog, interjektioner, og konversatoriske fragmenter blandes $\mathrm{i}$ et uopretteligt røre, hvor kun selve sproget står tilbage, løsrevet fra et sted hvorfra det tales, løsnet fra enhver karakter, sted eller position som siger det. Personlige pronominer som "jeg", "os" og "du" cirkulerer frit i teksten, som referentløse ord, tilsyneladende erstattelige med et hvilket som helst navn eller substantiv; de fremtræder nærmest på samme niveau som "vinen", "spurvene" og "tarmene", som logisk nok også udstyres med egenskaber og kunnen: Vinen opsnuser tørst (cestuy vin ... furette la soif); tørsten er lovstridig (comme d'abus), tarme vil være med i legen (Voycy trippes de jeu) og så fremledes. Det er selvfølgelig, fordi vi er i groteskens område, i groteskens krævende mave, hul som en grotte i bjerget eller forfatterens "osteformede hjerne" (le cerveau caseiforme), samtidig med at den svulmer som kuplen til Skt. Peter, og grotesken er, ved vi af erfaring, ingen singulær krop, men selve naturens drivende princip, det cyklisk cirkulerende princip som alle kroppe med nødvendighed er en del af, hvad Rabelais også på så sublim vis udvikler i den Fjerde Bogs syvoghalvtredsindstyvende kapitel om Messer Gaster.

Groteskens krop er altså denne Leviathan-lignende tarm - dette såvel befalende som ubønhørligt straffende princip for dem, som ikke lytter til dens lov (Et tout pour la trippe!) - hvor indenfor og udenfor, op og ned, indtagende som udspyende ikke længere er modsatrettede bevægelser. Og for kort at rekapitulere det, vi alle nu godt er klar over: Groteskens form består af heterogene elementer, hvor alting kan lægges til, trækkes fra og ændres, uden at helheden af den grund kommer til at mangle noget, fuldbyrdes på nogen særlig måde, eller perfektioneres til noget bedre eller mere fuldkomment. Alle disse harmoniens, proportionens og synekdokens så tit fejrede formprincipper er med hensyn til grotesken helt og aldeles omsonste, da dens struktur er helt igennem heterogen, dens topologi moebiusagtigt 'krængende' (samtidig konkav og konveks) og helheden er hverken mere eller mindre end mængden af delene, en tilfældig rent kvantitativ ansamling. Det interessante med Rabelais i almindelighed, og dette Gargantuas femte kapitel i særdeleshed, er nu det, at den ingen steder beskriver denne krop, struktur eller topologi (som det f.eks. er tilfældet mht. Messer Gasters ø i Fjerde Bogs 57. kapitel) - den taler det.

"Tale grotesk". Hvad vil det sige? Det vil, tror vi, først og fremmest sige, at den groteske krop, eller 
form, er indlejret i sproget. Det synes nu ikke at være således, at en grotesk krop eller form frembringer et grotesk sprog. Man kan sagtens forestille sig en meget velformuleret, velopdragen og følsom grotesk gestalt (f.eks. Elefantmanden), men denne velformulerede og helt igennem fornuftige groteske gestalt ville så være en visuel grotesk, en grotesk form. Den groteske krop giver ikke nødvendigvis en grotesk tale (Polyfem, eksempelvis, sådan som han skildres af digternes prins, er meget fornuftig). Men hvis den groteske tale, eller groteskens sprog, deler struktur med de formelementer og topologiske karakteristika, vi kender fra groteskens visuelle og formelle fremtrædelse, så kan følgelig de positionsløse udsagn, udsagn som ikke ved ud eller ind, op eller ned, modtagende eller udsendende, kort sagt: denne polyfoni, eller måske bedre: denne kakofoni af sprogligt 'materiale', give os en nøgle til groteskens funktion.

Denne 'sprogkrop' eller dette 'sprogrum' er nu ikke nødvendigvis hverken præget af stavefejl, grammatiske anomalier eller det rene volapyk (er Panurges Prug frest strinst sorgdmand strochdt drhds pag brleland ... (Pant., IX) en grotesk sætning?), men derimod synes groteskens sprogs fremmeste kendetegn at være, som vi her ser det praktiseret hos Rabelais, ikke at kunne kondensere sig til nogen anden krop end netop en uformelig sprogkrop og nærmest 'hængende' $i$ et udefinerbart og uspecificeret rum (ja, ganske som slagmarkens skrig, befalinger og interjektioner kan fryses ned, for, afhængig af de meteorologiske omstændigheder, ved et senere tilfælde at tø op og genlyde med al oprindelig kraft, som tilfældet er for les parolles gelées, de nedfrosne udsagn, i Quart Livre, LVI). Et sådant 'materialiseret' fysisk sprog 'mimer' snarere end repræsenterer, og kommer i sin sproghandling til at indlejre groteskens funktionsmåde.

\section{Entusiasme og dityrambe}

Et aspekt af et fysisk sprog er, at det er et talt sprog, og Rabelais' bøger er i eminent forstand bøger til at læse højt. Det at læse (højt) svarer her til at drikke, at læseren drikker, som bestod teksten af motz degelées, af smeltede ord. At skåle med bogen (eller teksten) svarer her til at proppe flasken op og at smage på ordene (som smelter på tungen), fx “træk, ræk, fyld, bland" (Garg., v) eller, hvorfor ikke, den afhuggede strubes "frygtelige ord":

Hin, hin, hin, hin, his, ticque, torche, lorgne, brededin, brededac, frr, frrr, frrr, bou, bou, bou, bou, bou, bou, bou, bou, traccc, trac, trr, trr, trr, trrr, trrrrrr [...] (Quart, LVI).

\section{Trinch?}

Rabelais understreger selv denne parallelitet mellem højtlæsning og druk i flere tilfælde, bl.a. ved afslutningen af I552-forordet til Quart Livre ("Men nu, host nu en god Gang med stærke Lunger, drik tre fulde Bægre, ryst Ørerne i Lave, saa skal I høre vidunderlige Ting om den gode og ædle Pantagruel” "I2) eller når han i forordet til Tiers livre skal til at fortælle om Diogenes entusiastiske rumlen med sin tønde: "Dersom I ikke har hørt tale om ham, saa skal jeg nu fortælle jer en Historie om ham for at sætte Smag paa Vinen (Drik da!) og paa Talen (Hør da!) [...]"..13

At forvandle, addere, tømme, fylde, vende, krænge og så fremledes er typisk for groteskens måde at fungere på (det synes heller ikke helt ligegyldigt hvilke udsagnsord, som dominerer den groteske kakofoni): Subjekter og objekter cirkulerer ustandseligt omkring sætningens udsagnsord, skifter plads, erstattes, dubleres og udsættes for en hvilken som helst vilkårlig metamorfose. Syntaktisk talt er groteskens funktion centreret omkring udsagnsordene; det er i denne logik i princippet underordnet, hvorvidt Polyfem sluger får eller får sluger Polyfem; hvorvidt sværd hugger pølser, pølser hugger sig selv eller hugger sværd til jernfilspån (som vi kender det - omtrent - fra andre steder i Rabelais' krøniker).

Udsagnsord, ja. Når Diogenes iagttog korinthernes flittige forsvarsforberedelser for at afværge Kong Filip af Makedoniens forestående belejring, noget fortørnet over at ingen kunne finde på at spørge ham om hans tjenester, og for at ingen skulle anklage ham for at gå omkring ledig og ørkesløs, rullede han med sin tønde til Crania, et forbjerg og en skøn esplanade nær Korinth,

[...] et en grande vehemence d'esprit desployant ses braz le tournoit, viroit, brouilloit, barbouilloit, hersoit, versoit, renver- 
soit, nattoit, grattoit, flattoit, barattoit, bastoit, boutoit, butoit, tabustoit, cullebutoit, trepoit, trempoit, tapoit, timpoit, estouppoit, destouppoit, detraquoit, triquotoit, tripotoit, chapotoit, croulloit, elançoit, chamailloit, bransloit, esbransloit, levoit, lavoit, clavoit, entravoit, bracquoit, bricquoit, blocquoit, tracassoit, ramassoit, clabossoit, afestoit, affustoit, baffouoit, enclouoit, amadouoit, goildronnoit, mittonnoit, tastonnoit, bimbelotoit, clabossoit, terrassoit, bistorioit, vreloppoit, chaluppoit, charmoit, armoit, gizarmoit, enharnachoit, empennachoit, caparassonnoit, le devalloit de mont à val, et præcipitoit par le Cranie $[\ldots] .{ }^{\mathrm{I} 4}$

Her kan man måske med rette tale om en syntaktisk beruselse (eller tømmermændslignende træthed), når denne mængde af omkring tresindstyve udsagnsord er placeret ved siden af hinanden, hvor teksten taber enhver retning, fodfæste eller forankring i subjekt eller objekt, men opløses i en svimlende rumlen-omkring den konstant repeterende endelse. Og det er også her, vi muligvis kan finde svaret på, hvordan man åbner en bog eller propper en flaske op, nemlig i sprogets, eller talens, inspirerede svimmelhed. Rabelais fortsætter, lige efter at Diogenes har forklaret sin omkringrumlen med sin tønde, sin tonneau Diogenic, med at præcisere nærmere, hvad dette er for en tilstand, med en af sine til lejligheden komponerede neologismer, l'Enthousiasme, som siden hen (med Nicolas Boileau Despréaux) kom at betyde så meget for den franske æstetiske diskussion:

Vent lidt, til jeg faar labbet en Slurk af denne Flaske, den er mit sande Helikon, min kaballinske Kilde, her alene henter jeg min Begejstrings Glød [mon unicque Enthusiasme]. Her, mens jeg drikker, overvejer og drøfter jeg, beslutter og vedtager jeg. Efter Epilogen ler jeg og skriver jeg, digter jeg og drikker jeg igen. Ennius skrev, mens han drak, og drak, mens han skrev. Æschylos - hvis man da kan stole paa Plutark i hans Symposiaca — drak, naar han digtede, og digtede, naar han drak. Homér skrev aldrig fastende. Cato skrev aldrig, for han havde drukket. Dette, for at I ikke skal sige, at jeg lever saaledes uden at have noget Eksempel for Øje fra de højt priste, ja højst værdsatte Poeter. (Tiers, Prol.) ${ }^{\text {I5 }}$

Denne entusiasme er tydeligvis lige så knyttet til drikkeriet som til skriveriet, hvilket jo fremgår af alle de højt lovpriste og højst værdsatte eksempler som Rabelais fremfører, men som også fremgår af sætningen je hume quelque traict de ceste bouteille, som ganske vist betyder det, som Falbe-Hansen oversatte det til ("jeg faar labbet en Slurk af denne Flaske"), men som også bærer tydelige konnotationer af, at forfatteren indainder afhandlinger fra sit vademecum, breviar eller tidebog, altså fra sine højt priste forbilleder. Entusiasmen vedrører inspirationen, altså indåndingen og indtagelsen, og denne entusiasme optræder hos Rabelais altid i forbindelse med Bacchus. Det er en enthusiasme Bacchique (Cinq., XLV); og når vore helte kommer til La dive Bouteille i den femte bog, går teksten også i de sidste par kapitler op i rene drikkeviser og ophøjede sprit-rim. Denne lyriske inspiration er uden tvivl noget, som Rabelais havde hugget fra Erasmus (som i sin tur refererer til Horats, Epodes XIX, 2-8): Non est Dithyrambus si bibit aquam..., dvs.:

Af vand kommer ingen dityramber, det vil sige, der vil ikke blive nogle dityramber hvis man drikker vand. Ingen begejstring hvor vinen savnes: Poeternes fantasi bliver svækket, hvis 
den ikke bliver ophidset af vinen. [...] Dityramberne blev sunget til Bacchi ære, som også selv blev kaldt dithyrambos, eftersom han er født to gange og derfor har passeret to porte. ${ }^{\text {I6 }}$

Dette motiv af bacchisk entusiasme, sang og druk er såvel i den tredje bogs prolog som i den femte bog altid sat $\mathrm{i}$ forbindelse med musernes kilde; det er en art guddommelig vin, som springer frem fra sin kilde, som ved et slag på et bjerg eller en sten.Vi kan gå ud fra, at det er derfor, det i den tredje bogs pro$\log$ hedder ma fontaine caballine; den kaballinske kilde, som sprang frem fra Helicon, da Pegasus' hov ramte den. Dityramben er en versfod, men en versfod uden meter, uden mål, det er den fod (eller hov), som rammer kilden, hvorfra vers udspringer, hvor teksten går over i sang, konversationen i inspiration, og den fureur poëtique hvor læser og forfatter mødes i teksten. Da forstår vi også bedre, hvorfor det netop var på Crania, at Diogenes maltrakterede sin tønde, og hvorfor det netop var på Golgatha, at Vor Frelser udtalte Guds ord sitio, "jeg tørster”. Samme motiv finder vi også i Jean Lemaire de Belges’ Illustrations de Gaule et Singularitez de Troye (I549), hvor Paris var blevet "beruset af et nyt begær", som fik ham til at "rase i ekstase og spekulere over ophøjede ting", efter at have drukket af den ædle saft fra "la fontaine Creïse". ${ }^{17}$

Det er - håber jeg - denne huleformede kilde, dette dødeskallebjerg, dette Helicon og denne hl. Quenets bug (som skal være tidens argot for bager) vi ramte med skålen og som derved aktualiserer kiasmen mellem verbet og vinen, mellem bogen og flasken (beuvant escrivoit, escrivant beuvoit). Midt i denne kiasme af verbum og vin, af bog og flaske, finder læseren pludseligt fortællerjeget placeret inde $i$ teksten (Où estez vous?), dvs. som Alcofribas på Pantagruels tunge (langue). Og hvis fortællerjeget Alcofribas er på Pantagruels tunge, og vi læser ordene, som forfatteren har lagt derpå for at smelte (les parolles gelées), så betyder det, at vi, læserne, er Pantagruel, vi, som udbringer denne tørstende skål, er denne horrificque et espoventable geant, dvs. den groteske krop. Da har vi åbnet bogen, da har vi, ganske som Epistemon, Odysseus, Vergil, Alexander eller de andre underjordiske rejsende været nede ved kilden, i Pantagruels bug, denne fontaine Creüse for at udbringe vor skål, til teksten, som ligger, smeltende, på vores tørstende tunge.

Lad os ikke gøre det tungere end det er, I må tro det eller lade være, og afslutte med Rabelais' eget dekret:

Hæng i medVinen, Kammerater, drik løs af fulde Bægre! Dersom I ikke finder den god, saa lad den staa. Jeg er ikke én af disse Fyldebøtter, der med Magt, Forhaanelser og Vold tvinger Venner og Fæller til at drikke — og pæle den, til de segner, hvad værre er. Enhver ordentlig Bægersvinger, enhver ordentlig Podagrist, der kommer tørstig til min Tønde, kan lade være med at drikke, hvis han ikke vil; men dersom de vil, og Vinen falder i deres Herligheders Herligheds Smag, kan de drikke frejdigt, frit og dristigt — og gratis, uden at spare paa den. Det er min Forordning. (Tiers., Prol.) ${ }^{18}$

\section{Noter}

I. François Rabelais: Gargantua og Pantagruel, overs. C.E. Falbe-Hansen. Bd. I, p. 5 (1945). Det hedder i den sidste af forfatteren autoriserede udgave: "Or esbaudissez vous mes amours, et guayement lisez le reste tout à l'aise du corps, et au profit des reins. Mais escoutez vietz d'azes, que le maulubec vous trousque: vous soubvienne de boyre à my pour la pareille: et je vous plegeray tout ares metys." CEuvres complètes. Ed. Mireille Huchon. Paris, Gallimard, I994, p. 8.

2. "Gens de bien, Dieu vous saulve et guard. Où estez vous? Je ne vous peuz veoir. Attendez que je chausse mes lunettes. Ha, ha. Bien et beau s'en va Quaresme, je vous voy. Et doncques? Vous avez eu bonne vinée? à ce que l'on m'a dict. Je n'en serois en piece marry. Vous avez remede trouvé infaillible contre toutes alterations?" Ed. Huchon, p. 523 .

3. Ed. Falbe-Hansen, I, p. 4. Ed. Huchon, p. 7: “... qui paradventure beviez comme moy".

4. Vor kursiv. Ed. Huchon: "Pourtant interpretez tous mes faictz et mes dictz en la perfectissime partie, ayez en reverence le cerveau caseiforme qui vous paist de ces belles billes vezées, et à vostre povoir tenez moy tousjours joyeux." (Garg., Prol.).

5. "Hen hen, il est à une aureille, bien drappé ...". Ed. Huchon, p. 20). Ingen af de kommentatorer vi har for hånden (Euvres. Edd. Burgaud des Marets \& Rathery. 3. éd. Paris I893, Euvres complètes. Ed. Plattard. Paris I948, Petersen Dyggves svenske oversættelse (Stockholm 1945), Urquharts engelske, Falbe-Hansens eller Huchons) kobler dette udtryk til beruselse, eller stangstivhed for den sags skyld, men til vinens kvalitet; krus med ét øre indeholdt 
bedre vin, og derfor 'silkeblødt', med henvisning til en af Rabelais' vigtigere inspirationskilder, Maistre Pierre Pathelin, hvor det hedder (v. I92-193):

C'est ung tresbon drap de Rouën,

Je vous prometz, et bien drappé.

(Her fra: Jeux et Sapience du Moyen Age. Ed. Albert Pauphilet. Paris: Gallimard (Pléiade), I95I, p. 289.) Men vi vil fastholde, at det også refererer til drankeren, som på svensk, "är på örat". Uventet støtte til denne antagelse får vi fra oversætternes dydsmønster Søren Broberg, som til passagen "Det er det bare Fløjl, der er sat paa Flasker. Det er for eet Øre”, bemærker i en fodnote: “Dette Udtryk forekommer ofte hos Rabelais. Der tænkes paa den Vellyst, med hvilken man lægger Hovedet paa Siden, med det ene Øre i Vejret, efter at have drukket et godt Glas Vin.” (Mester Frants Rabelais ... i Udtog. Kjøbenhavn I884, pp. 35-36).

6. I denne prolog bliver temaet brevaire og drikkeri meget tydeligt gennemspillet. Cf. Huchon, ed., p. 7I7.

7. "Plus dictes que le vin du tiers livre ha esté à vostre goust, et qu'il est bon.Vray est, qu'il y en avoit peu, et ne vous plaist ce, que l'on dict communement, 'Un peu et du bon': plus vous plaist ce, que disoit le bon Evispande Verron, 'Beaucoup et du bon'." Ed. Huchon, p. 7I7.

8. Ed. Falbe-Hansen, I, p. 2-3. "Crochetastes vous oncques bouteilles? Caisgne. [i.e. chienne!] Reduisez à memoire la contenence qu'aviez. Mais veistes vous onques chien rencontrant quelque os medulare? [...] Si veu l'avez: vous avez peu noter de quelle devotion il le guette: de quel soing il le guarde: de quel ferveur il le tient, de quelle prudence il l'entomme: de quelle affection il le brise: et de quelle diligence il le sugce. [...] À l'exemple d'icelluy vous convient estre saiges pour fleurer, sentir, et estimer ces beaulx livres de haulte gresse, legiers au prochaz: et hardiz à la rencontre.” Ed. Huchon, pp. 6-7.

9. Ed. Falbe-Hansen, II, I4. "Car alors que sa mere Badebec l'enfantoit, et que les sages femmes attendoyent pour le recepvoir, yssirent premier de son ventre soixante et huyt tregeniers chascun tirant par le licol un mulet tout chargé de sel, aprés lesquelz sortirent neuf dromadaires chargés de jambons et langues de beuf fumées, sept chameaulx chargez d'anguillettes, puis .xxv. charretées de porreaulx, d'aulx, d'oignons, et de cibotz: ce que espoventa bien lesdictes saiges femmes, mais les aulcunes d'entre elles disoyent. 'Voicy bonne provision aussy bien ne beuyons nous que lachement non en lancement, cecy n'est que bon signe, ce sont aguillons de vin."' Ed. Huchon, p. 224 .

Io. Da alle oversættelser jeg kender - Falbe-Hansens inklusive - synes at anstrenge sig for at finde fragmenter af narrativ sammenhæng, hvor de efter min bedste overbevisning finder mere end hvad der står, har jeg lavet en relativ ordret oversættelse, men selvfølgelig baseret på Falbe-Hansens. Det heder i Huchons udgave: "Puis entre- rent en propos de resjeuner on propre lieu. Lors flaccons d'aller: jambons de troter, goubeletz de voler, breusses de tinter. 'Tire, baille, tourne, brouille. Boutte à moy, sans eau, ainsi mon amy fouette moy ce verre gualentement, produiz moy du clairet, verre pleurant. Treves de soif. Ha faulse fiebvre, ne t'en iras tu pas? Par ma fy ma commere je ne peuz entrer en bette. Vous estez morfondue m'amie. Voire. Ventre sainct Qenet parlons de boire. Je ne boy que à mes heures, comme la mulle du pape. Je ne boy que en mon breviaire, comme un beau pere guardian. Qui feut premier soif ou beuverye? Soif. Car qui eust beu sans soif durant le temps de innocence? Beuverye. Car prinatio presupponit habitum. Je suis clerc. Focundi calices quem non fecere disertum."

II. "Je me porte pour appellant de soif, comme d'abus. Paige relieve mon appel en forme. Ceste roigneure. Je souloys jadis boyre tout: maintenant je n'y laisse rien. Ne nous hastons pas, et amassons bien tout.Voycy trippes de jeu, et guodebillaux d'envy de ce fauveau à la raye noire. O pour dieu estrillons le à profict de mesnaige. Beuvez ou je vous. Non, non. Beuvez je vous en prye. Les passereaux ne mangent si non que on leurs tappe les queues. Je ne boy si non qu'on me flatte. Lagona edatera. Il n'y a raboulliere en tout mon corps, où cestuy vin ne furette la soif. Cestuy cy me la fouette bien.” Ed. Huchon, p. I9.

I2. "Or en bonne santé toussez un bon coup, beuvez en trois, secouez dehait vos aureilles, et vous oyrez dire merveilles du noble et bon Pantagruel." Ed. Huchon, p. 535 . I3. Ed. Huchon, p. 346: "Si n'en avez ouy parler, de luy vous veulx presentement une histoire narrer, pour entrer en vin, (beuvez doncques) et propous, (escoutez doncques)".

I4. Hos Falbe-Hansen hedder det: “[...] og greben af voldsom Sindsbevægelse strakte han sine Arme ud og drejede, snurrede, rystede og krystede dem, æltede og væltede, flettede og nettede, striglede og pryglede, klappede og lappede, skramlede og ramlede, trippede og vippede, stampede og tampede, stoppede og proppede og loppede, strikkede og hikkede og rykkede, styrtede og startede, ævlede og kævlede, rokkede og brokkede, sjaskede og vaskede, sømmede og rømmede, styrede og fyrede og tyrede, asede og masede og kvasede, stillede og pillede, tøjlede og gøglede, begede og stegede og legede, vrøvlede og høvlede og støvlede, snittede og kittede og splittede, charmerede og armerede, spidsede og ridsede, rustede og pustede, pundrede og pyntede og væltede Tønden fra Bjerg til Dal, rullede den ned ad Krania [...]” (III, pp. 4-5).

I5. Ed. Falbe-Hansen, III, 7. Ed. Huchon. p. 349: “Attendez un peu que je hume quelque traict de ceste bouteille: c'est mon vray et seul Helicon: c'est ma fontaine Caballine: c'est mon unicque Enthusiasme. Icy beuvant je delibere, je discours, je resoulz et concluds. Aprés l'epilogue je riz, j'escripz, je compose, je boy. Ennius beuvant escrivoit, 
escrivant beuvoit. Æschylus (si à Plutarche foy avez in Symposiacis) beuvoit composant, beuvant composoit. Homere jamais n'escrivit à jeun. Caton jamais n'escrivit que aprés boyre. Affin que ne me dictez ainsi vivre sans exemple des bien louez et mieulx prisez".

I6. "Non est Dithyrambus si bibit aquam, id est, haud dithyrambus est, aquam si potiret. Non adest hilaritas, quum deest vinum: languet poetarum ingenium ni vino concalescat. [...] Dithyrambi canebantur in honorem Bacchi: qui et ipse diquramboV dictus est, quod bis natus velut e duabus ianuis prodierit." Des. Erasmi Roterodam Adagiorum Chiliades .... Basel: Froben, I5I5. IV, iii, 58 $(=3258)$.

I7. Jean Lemaire de Belges: Guvres, ed. J. Stecher. Genève: Slatkine, I969 (Louvain I882-85), p. I76. Vor kursiv.

I8. Ed. Falbe-Hansen, III, 9-7. "Enfans beuvez à pleins guodetz. Si bon ne vous semble, laissez le. Je ne suys de ces importuns Lifrelofres, qui par force, par oultraige et violence, contraignent les Lans et compaignons trinquer, voire caros et alluz, qui pis est. Tout beuveur de bien, tout Goutteux de bien, alterez, venens à ce mien tonneau, s'ilz ne voulent ne beuvent: s'ilz voulent, et le vin plaist au guoust de la seigneurie de leurs seigneuries, beuvent franchement, librement, hardiment, sans rien payer, et ne l'espargnent. Tel est mon decret." Ed. Huchon, p. 35 I. 